\title{
COMPOSIÇÃO QUÍMICA DE SEMENTES DE MANIHOT CATINGAE ULE (')
}

\author{
JOĀO PAULO FEIJĀO TEIXEIRA $(2,3)$
}

\begin{abstract}
RESUMO
Analisaram-se sementes de Manihot catinyae Ule, vulgarmente conhecida como maniçoba-brava ou maniçobeira-de-caatinga, coletadas de plantas existentes no Centro Experimental de Campinas, em dois anos consecutivos. Os resultados mostraram que as sementes contêm, em média, $11,6 \%$ de óleo e $8,5 \%$ de proteina na matéria seca. $O$ óleo é composto dos ácidos graxos palmítico $8,5 \%$, esteárico $1,3 \%$, oléico $8,4 \%$, linoléico $81,6 \%$ e linolênico 0,3\%. Do óleo extraído, foi possivel isolar ácido linoléico, principal constituinte, para utilização em análises quimicas como substrato para a enzima lipoxigenase.
\end{abstract}

Termos de indexação: maniçoba-brava, Manihot catingàe Ule, ácido linoléico, óleo, proteina.

Manihot catingae Ule, euforbiácea, é árvore de 2 a 5 metros de altura, glabra, com folhas caducas e cujos frutos sāo cápsulas globosas e rugosas. O local de origem dessa espécie é o Estado da Bahia, onde recebe os nomes vulgares de maniçobeira-da-caatinga e maniçoba-brava. Segundo PIO CORREA (1978), as plantas do gênero Manihot, conhecidas como maniçoba ou maniçobeira, produzem látex transformável em borracha, de segunda qualidade, mas aproveitável para alguns fins.

\footnotetext{
(1) Recebido para publicação em 3 de dezembro de 1986.

(2) Seção de Fitoquímica, Instituto Agronômico, Caixa Postal 28, 13001 Campinas (SP).

(3) Com bolsa de pesquisa do CNPq.
} 
As maniçobeiras em geral produzem, além desse látex, sementes oleaginosas também utilizadas na alimentação de suínos e outros animais (PIO CORREA, 1978).

A avaliação do potencial de utilização das sementes como fonte de óleo é necessária, pois, em certas situações e locais, julga-se importante dispor de oleaginosas arbóreas, como ocorre com espécies de Jatropha (TEIXEIRA, 1987).

Não foram encontradas, porém, informações sobre a composição química das sementes, cuja produção, observada no Centro Experimental de Campinas, se apresenta elevada, e cujo aspecto é similar ao das sementes de Ricinus e Jatropha.

O presente estudo tem por objetivo avaliar as sementes dessa euforbiácea visando aquilatar seu potencial como planta oleaginosa.

\section{Material e Métodos}

Em área do Centro Experimental de Campinas, coletaram-se sementes provenientes de várias árvores de Manihot catingae Ule, em 1985 e 1986. As sementes, dispostas em duas amostras por ano, foram moídas (40 mesh) e analisadas. O teor de óleo foi determinado através da extração com solvente hexano em extratores "butt" por oito horas, seguida de avaliação gravimétrica. O teor de proteína foi avaliado, multiplicando-se por 6,25 o conteúdo de nitrogênio total, pelo método Kjeldahl (TEIXEIRA et al., 1985), e os ácidos graxos, por cromatografia gasosa, coluna de 1,80 metro, com succinato de dietileno glicol (Degs), $180^{\circ} \mathrm{C}$, após saponificação do óleo e esterificação dos ácidos graxos (TEIXEIRA et al., 1985).

\section{Resultados e Discussão}

Os frutos coletados pesavam, em média, $2,40 \mathrm{~g}$ e continham três sementes com peso médio de $0,72 \mathrm{~g}$ cada uma.

Os teores de óleo e proteína das sementes foram relativamente baixos (Quadro 1) e não variaram nos dois anos de amostragem. As sementes apresentam, porém, em média, $78 \%$ de seu peso total como casca. Assim, apenas $22 \%$ do peso se refere à amêndoa, onde está concentrado todo óleo e proteína. Levando em conta esses dados, a amêndoa apresenta o teor aproximado de $52 \mathrm{e}$ $38 \%$ de óleo e proteína respectivamente. A composição do óleo dessa euforbiácea quanto a ácidos graxos é muito semelhante ao relatado para Jatropha podagrica (TEIXEIRA, 1987), por seu alto teor de ácido linoléico (82\%) (Quadro 1 e Figura 1). 
QUADRO 1. Composição quimica de sementes de Manihot catingae Ule. Campinas, SP

\begin{tabular}{|c|c|c|c|c|c|c|c|}
\hline \multirow{2}{*}{ Amostra (1) } & \multirow{2}{*}{ Óleo } & \multirow{2}{*}{ Proteína } & \multicolumn{5}{|c|}{ Ácidos } \\
\hline & & & Palmitico & Esteárico & Oléico & Linoléico & Linolênico \\
\hline & $-\mathrm{MS}$ & - & - & -2 & - Óleo\% & $\ldots$ & \\
\hline 1 & 12,0 & 8,2 & 7,7 & 1,6 & 8,4 & 82,1 & 0,3 \\
\hline 2 & 11,2 & 8,6 & 7,6 & 1,6 & 8,9 & 81,5 & 0,4 \\
\hline 3 & 11,9 & 8,6 & 9,0 & 1,0 & 8,0 & 81,6 & 0,3 \\
\hline 4 & 11,1 & 8,4 & 9,5 & 1,1 & 8,3 & 81,0 & 0,4 \\
\hline Média & $11,6 \pm 0,5$ & $8,5 \pm 0,2$ & $8,5 \pm 0,9$ & $1,3 \pm 0,3$ & $8,4 \pm 0,4$ & $81,6 \pm 0,5$ & $0,35 \pm 0,06$ \\
\hline
\end{tabular}

(1) Amostras 1 e 2 coletadas em 1985; 3 e 4, em 1986.

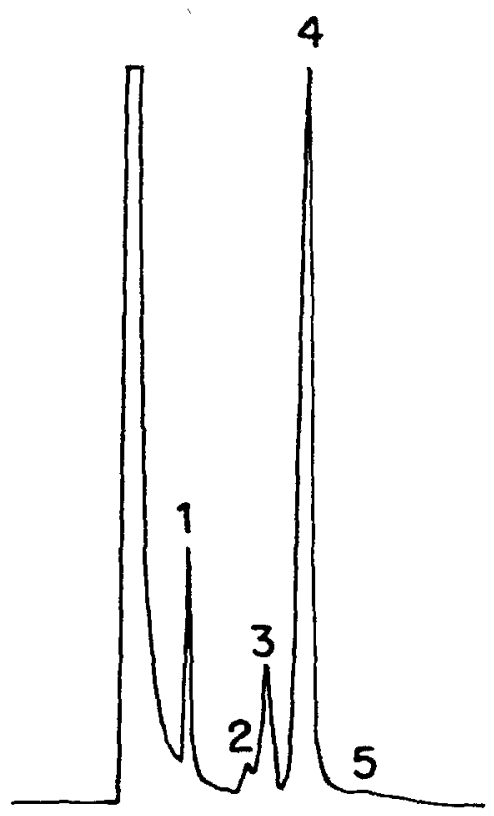

FIGURA 1. Composição em ácidos graxos do óleo de sementes de Manihot catingae Ule: 1: palmítico; 2: esteárico; 3: oléico; 4: linoléico, e 5: linolênico. 
Pela disponibilidade de sementes e elevado teor de ácido linoléico, tem-se conseguido extrair e isolar esse ácido graxo do óleo da espécie, obtendo-se, com bom rendimento, produto de pureza adequada para emprego em análises quimicas. É possivel, pois, substituir outras espécies utilizadas como fonte desse ácido (TEIXEIRA, 1987) e mesmo os produtos existentes no comércio para algumas aplicações como, por exemplo, o substrato, para a determinação de atividade da enzima lipoxigenase. Essa aplicaçāo se reveste de importância, visto que o produto comercial tem custo aproximado de 10 OTNs/grama, o que é extremamente superior ao necessário para obter ácido linoléico a partir de sementes de Manihot catingae.

\section{AGRADECIMENTOS}

autor agradece ao Pesquisador Científico Condorcet Aranha, da Seção de Botânica Econômica, a classificação da espécie estudada, e aos seguintes funcionários da Seção de Fitoquímica: Siverino Antonio Pansieri, a coleta de amostras e análises químicas, e Miriam A.B.Pissolatto, as análises cromatográficas.

\section{SUMMARY}

\section{CHEMICAL COMPOSITION OF MANIHOT CATINGAE SEEDS}

Samples of Manihot catingae Uie seeds were collected in the Experimental Station of Instituto Agronômico, Campınas, State of São Paulo, Brazil, during two successive years. Seeds were analysed for protein, oil and fatty acids. On the average the seeds had $11.6 \%$ and $8.5 \%$ of oil and protein contents, respectively. The oil composition in fatty acids, was: palmitic $8.5 \%$, stearic $1.3 \%$, oleic $8.4 \%$, linoleic $81.6 \%$, and linolenic $0.3 \%$. This fatty acid composition revealed the importance of this oil as a source of linoleic acid for analytical chemical purposes, which was isolated and used as substrate for the lipoxygenase enzyme.

Index terms: Manihot catingae Ule, linoleic acid, oil, protein.

\section{REFERÊNCIAS BIBLIOGRÁFICAS}

PIO CORREA, M. Maniçoba. In: _. Dicionário das plantas úteis do Brasil e das exóticas cultivadas. Rio de Janeiro, Ministério da Agricultura, 1978. v.5, p.90-94.

TEIXEIRA, J.P.F. Teor e composiçāo do óleo de sementes de Jatropha spp. Bragantia, Campinas, 46(1):151-157, 1987.

; RAMOS, M.T.B.; MORAES, R.M.; FARACO, M.H. \& MASCARENHAS, H.A.A. Acúmulo de substâncias de reserva em grãos de soja. I. Matéria seca, óleo e ácidos graxos. Bragantia, Campinas, 44(1):295-309, 1985. 